\title{
16S rRNA gene and 18S rRNA gene diversity in microbial mat communities in meltwater ponds on the McMurdo Ice Shelf, Antarctica
}

\author{
Eleanor E. Jackson ${ }^{1,2} \cdot \operatorname{lan}$ Hawes $^{3} \cdot$ Anne D. Jungblut $^{1}$ (i) \\ Received: 30 April 2020 / Revised: 24 February 2021 / Accepted: 4 March 2021 / Published online: 18 March 2021 \\ (c) The Author(s) 2021
}

\begin{abstract}
The undulating ice of the McMurdo Ice Shelf, Southern Victoria Land, supports one of the largest networks of ice-based, multiyear meltwater pond habitats in Antarctica, where microbial mats are abundant and contribute most of the biomass and biodiversity. We used 16S rRNA and 18S rRNA gene high-throughput sequencing to compare variance of the community structure in microbial mats within and between ponds with different salinities and $\mathrm{pH}$. Proteobacteria and Cyanobacteria were the most abundant phyla, and composition at OTU level was highly specific for the meltwater ponds with strong community sorting along the salinity gradient. Our study provides the first detailed evaluation of eukaryote communities for the McMurdo Ice Shelf using the 18S rRNA gene. They were dominated by Ochrophyta, Chlorophyta and Ciliophora, consistent with previous microscopic analyses, but many OTUs belonging to less well-described heterotrophic protists from Antarctic ice shelves were also identified including Amoebozoa, Rhizaria and Labyrinthulea. Comparison of 16S and 18S rRNA gene communities showed that the Eukaryotes had lower richness and greater similarity between ponds in comparison with Bacteria and Archaea communities on the McMurdo Ice shelf. While there was a weak correlation between community dissimilarity and geographic distance, the congruity of microbial assemblages within ponds, especially for Bacteria and Archaea, implies strong habitat filtering in ice shelf meltwater pond ecosystems, especially due to salinity. These findings help to understand processes that are important in sustaining biodiversity and the impact of climate change on ice-based aquatic habitats in Antarctica.
\end{abstract}

Keywords Microbial mat $\cdot 16 \mathrm{~S}$ rRNA $\cdot 18 \mathrm{~S}$ rRNA $\cdot$ Aquatic ecosystems $\cdot$ Ice shelf $\cdot$ Antarctica

\section{Introduction}

Microbial mats are horizontally stratified biofilms, typically comprising Bacteria and protists often embedded in a polymeric matrix, within which steep physicochemical gradients are formed. Many are phototrophic, with Cyanobacteria (often filamentous) frequently dominating the photosynthetic component. Microbial mat thickness ranges from a few layers of cells to elaborate, $\mathrm{cm}$-scaled structures, the latter typically developing in locations where physical

Anne D. Jungblut

a.jungblut@nhm.ac.uk

1 Life Sciences Department, Natural History Museum, Cromwell Road, 18, London SW7 5BD, UK

2 Present Address: School of Biological Sciences, University of Reading, Reading, UK

3 Coastal Marine Field Station, University of Waikato, 58 Cross Road, Tauranga 3110, New Zealand and/or biotic disturbance are minimal (Stal 2012). They are abundant in extreme aquatic environments, where grazers such as insects and animals are excluded by growth conditions (e.g. geothermal or hypersaline environments) or by extreme isolation (e.g. perennially ice-covered polar lakes). Such conditions favour the development of thick or elaborate microbial mats through slow, uninterrupted accumulation of biomass in the absence of bioturbation, such that phototropic microbial mats can come to dominate biomass, productivity and biodiversity (Jungblut and Neilan 2010a; Stal 2012; Ward et al. 2012; Wong et al. 2016; Jungblut and Vincent 2017; Hawes et al. 2019).

The biogeochemical gradients that typically occur in microbial mats are related to stratification of organisms and function. Across a wide range of environments, similar biological stratifications emerge, with oxygenic phototrophs dominating the upper (illuminated, oxic) parts of the mat structure, giving way to anoxygenic production and heterotrophic aerobic and anaerobic processes with increasing 
depth, declining irradiance and increasing hypoxia (Armitage et al. 2012; Stal 2012, Schneider et al. 2013; references within; Jungblut et al. 2016). Microbial assembly is potentially shaped by a combination of factors including environmental filtration, biotic interactions, biogeographic dispersal limitations and neutral stochastic resource-independent processes (Rosindell et al. 2011; Leibold and Chase 2018). Although studies have captured the bacterial diversity of many extreme environments, including the Polar Regions, the relative importance of selective and neutral processes to community assembly, for Bacteria, Archaea and Eukaryotes, is still not well understood. It is important, however, for understanding biodiversity in extreme environments, and particularly for Antarctica, with the potential acceleration of environmental change that may accompany polar warming (Cowan and Tow 2004; Kennicutt et al. 2014; IPCC 2019).

Microbial mats in meltwater ponds on the McMurdo Ice Shelf (Fig. 1), Antarctica, are located in close proximity and cover a range of environmental conditions (Online Resource 1). These features make them particularly well suited for the evaluation of selection processes on microbial mat communities (Howard-Williams et al. 1989; Vincent and James 1996; De Los Ríos et al. 2004; Jungblut and Neilan 2010b; Archer et al. 2015; Sutherland et al. 2020). Salinity, in particular, varies greatly between ponds. Meltwater ponds become salinised when evaporation and sublimation becomes a significant component of water balances (Sutherland 2009; Hawes et al. 2014). The McMurdo Ice Shelf meltwater ponds have also been suggested to be source of biological material for ice-free regions in Southern Victoria Land (Howard-Williams et al. 1990a, b).

Several studies have documented 16S rRNA gene Bacteria and Archaea diversity in relation to environmental variables on the McMurdo Ice Shelf. They tend to report wide environmental tolerance within taxa but have inferred some environmental filtering, with salinity playing a role in cyanobacterial and heterotrophic bacterial community assembly

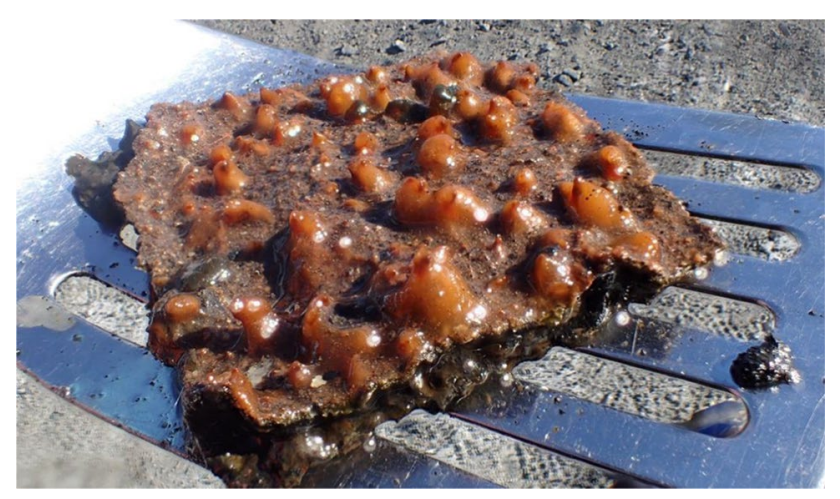

Fig. 1 Microbial mat collected from Pond Seventy, McMurdo Ice Shelf, Antarctica
(Jungblut et al. 2005; Archer et al. 2014). These exploratory investigations tend to be based on a single sample per pond, and do not allow a robust comparison of within- and between-pond variance.

No study has yet examined microbial Eukaryotes using 18S rRNA gene high-throughput sequencing (Jungblut et al. 2012b; Varin et al. 2012) and evaluated if microbial Eukaryotes in microbial mats in ice shelf meltwater ponds respond in the same way to environmental condition as Bacteria and Archaea. Previous surveys of microbial Eukaryotes have been restricted to microscopic assessments of diatoms and microfauna, clone library surveys and a metagenome from one meltwater pond on the McMurdo Ice Shelf, Antarctica (Suren 1990; Jungblut et al. 2012a, b; Varin et al. 2012; Archer et al. 2015; Sutherland et al. 2020). Therefore, the objectives of this study are to use 16S and 18S rRNA gene sequencing and community structure analysis to examine and compare Bacteria and Archaea, and eukaryotic communities within, and between, ponds with contrasting salinities on the McMurdo Ice Shelf. We utilise multiple, independent samples from ponds with salinities ranging from fresh $\left(126 \mu \mathrm{S} \mathrm{cm}^{-1}\right)$ to hypersaline $\left(41,300 \mu \mathrm{S} \mathrm{cm} \mathrm{cm}^{-1}\right)$ to address the following hypotheses: (1) Salinity is the primary driver of inter-pond variability for Bacteria and Archaea, in addition to microbial Eukaryotes, and (2) environmental filtering plays a role in the assembly of microbial mat community composition in ice shelf meltwater ponds in Antarctica.

\section{Materials and methods}

\section{Study site and sample collection}

The McMurdo Ice Shelf (MIS) ablation zone comprises an area of about $1500 \mathrm{~km}^{2}$. It is a $10-50-\mathrm{m}$-thick marinederived ice layer floating on the sea (Swithinbank 1970; Howard-Williams et al. 1990a, b) and located in Southern Victoria Land, Eastern Antarctica. Annual summer thawing creates ponds in depressions of the undulating surface of the ice shelf, formed from local ice and snow melt (Vincent and James 1996). The ponds, which cover $20 \%$ of the ice shelf surface (De Mora et al. 1994), have individually distinct geochemical environments driven by variations in melt generation and variable input from marine-derived surface sediments and salts released by the melting ice (Cowan and Tow 2004; Lyons et al. 2012). Almost all of these ponds contain thick microbial mats that cover most of the pond floor (Hawes et al. 2018).

Microbial mat samples were collected from the MIS ponds on 16 and 17 January 2017 (Fig. 2). Mat samples were taken from Skua Pond (78.01330'S $\left.165.55188^{\prime} \mathrm{E}\right)$, Duet Pond (78.01588'S 165.54936'E), Salt Pond (78.01588'S 165.54936'E), Brack Pond 
Fig. 2 Map showing the six ponds Skua, Conophyton, Brack, Duet and Salt Ponds as well as Pond Seventy on the McMurdo Ice Shelf near Bratina Island where microbial mats were collected for the study, Antarctica; small inset showing the location of Bratina Island in relation to the McMurdo Sound and Ross Island, Antarctica

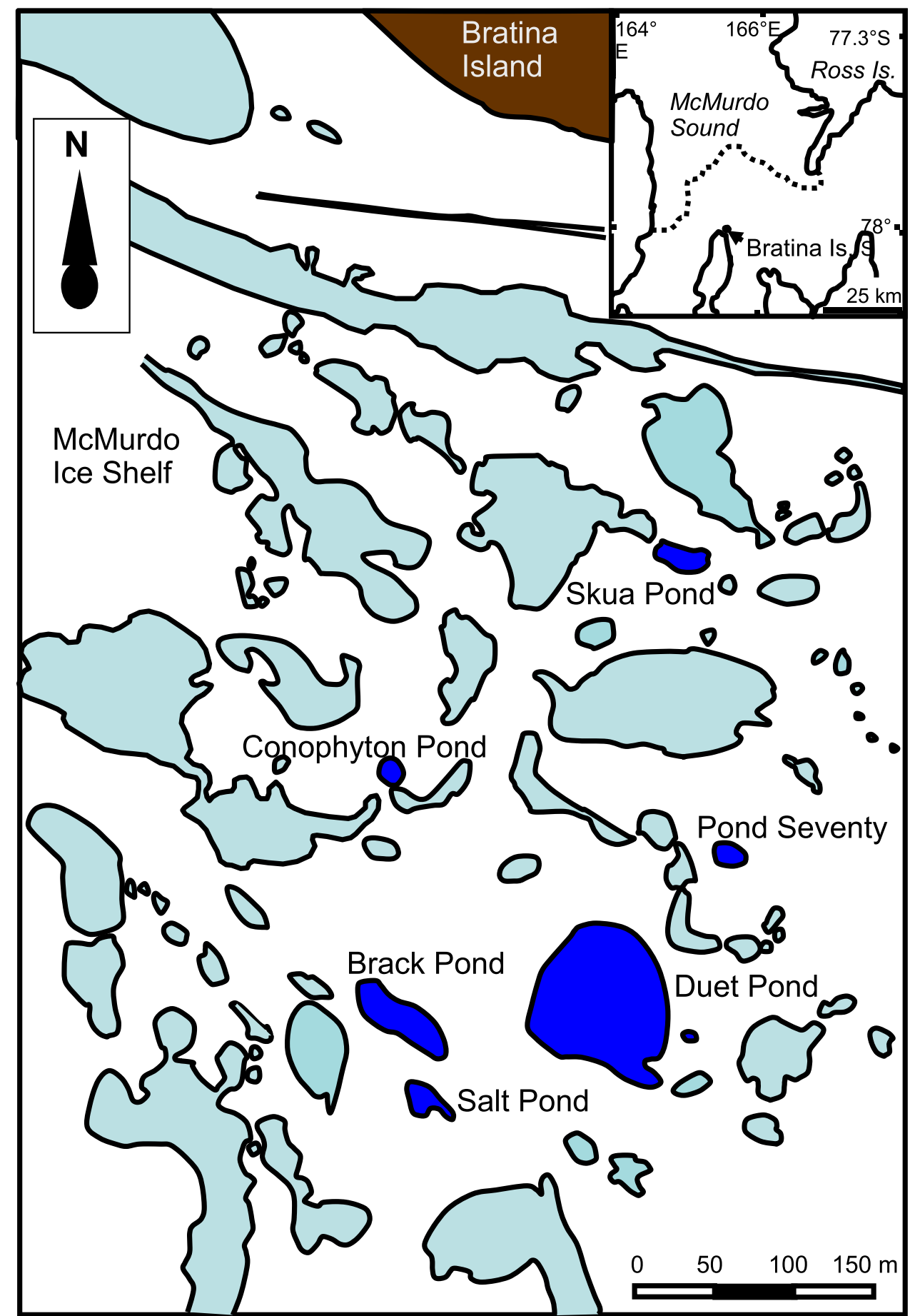

(78.01580'S 165.54502'E), Conophyton Pond (78.01400'S $\left.165.54400^{\prime} \mathrm{E}\right)$ and Pond Seventy (78.01486'S $\left.165.55169^{\prime} \mathrm{E}\right)$. The ponds were selected because they represent the range of salinities that can be found on the McMurdo Ice Shelf (Howard-Williams et al. 1989). For each pond, six microbial mat samples were taken at $1 \mathrm{~m}$ intervals along a transect, using a sterile stainlesssteel spatula, and transferred to $5 \mathrm{ml}$ cryovial tubes. The transect was along the littoral zone and the mat samples were all collected from the same depth (Online Resource 1). Samples were frozen at $-20^{\circ} \mathrm{C}$ and transported to the Natural History Museum, London, UK. Measurements of $\mathrm{pH}$, conductivity and temperature were taken at each sampling location along the transect for every pond, with a HQ40d portable multimeter (Hach, Loveland, CO). 


\section{DNA extraction, polymerase chain reaction (PCR), purification, quantification and Illumina MiSeq sequencing}

DNA was extracted from $0.4 \mathrm{~g} \pm 0.1 \mathrm{~g}$ of each sample using a PowerBiofilm DNA isolation Kit (MO BIO Laboratories, Carlsbad, CA) according to the manufacturer's instructions. Samples were PCR amplified with 16S rRNA gene primers containing MiSeq sequencing adapters, a 12-nucleotide Golay barcode on the reverse primer (Caporaso et al. 2012). For $16 \mathrm{~S}$ rRNA gene sequencing, the forward primer $515 \mathrm{~F}$ and its reverse complement $806 \mathrm{R}$ were used to amplify 260 bp of the V4 hyper-variable region of the Bacteria and Archaea 16S small ribosomal subunit rRNA (Caporaso et al. 2011). For $18 \mathrm{~S}$ rRNA gene sequencing, the primer pair $1391 \mathrm{~F}$ and EukBr were used to amplify approximately $130 \mathrm{bp}$ of the V9 hyper-variable region of the eukaryote small ribosomal subunit rRNA (Amaral-Zettler et al. 2009). PCRs were run using $20 \mu \mathrm{l}$ reaction volumes with $9.84 \mu \mathrm{l}$ sterile PCR-grade water, $0.8 \mu \mathrm{l}$ of $20 \mathrm{mg} / \mathrm{ml}$ bovine serum albumin (BSA), $4 \mu \mathrm{l} 5 \mathrm{X}$ GoTaq reaction buffer (Promega, Madison, WI), $2 \mu \mathrm{l}$ of $25 \mathrm{M} \mathrm{MgCl}_{2}, 0.16 \mu \mathrm{l}$ of $200 \mathrm{M} \mathrm{dNTP}$ and $0.2 \mu \mathrm{l}$ GoTaq G2 DNA polymerase ( $5 \mathrm{U} / \mu 1$ Promega, Madison, WI). $1 \mu \mathrm{l}$ of $10 \mu \mathrm{M}$ reverse primer and $1 \mu \mathrm{l}$ of $10 \mu \mathrm{M}$ forward primer were used. To prevent contamination, the reaction mix was prepared under a laminar hood after sterilisation of equipment and surfaces with UV light for $30 \mathrm{~min}$. Each sample was run in triplicate and a negative control was included for each sample. Different concentrations of DNA for each replicate $(0.5,1.0$ and $1.5 \mu \mathrm{l})$ were used to compensate for potential amplification bias. DNA was amplified in a thermocycler running a program of $94{ }^{\circ} \mathrm{C}$ for $3 \mathrm{~min}$; followed by 35 cycles of $94{ }^{\circ} \mathrm{C}$ for $45 \mathrm{~s}$; $50{ }^{\circ} \mathrm{C}$ (16S rRNA gene amplification) or $56{ }^{\circ} \mathrm{C}$ (for $18 \mathrm{~S}$ rRNA gene amplification) for $60 \mathrm{~s} ; 72{ }^{\circ} \mathrm{C}$ for $90 \mathrm{~s}$; and a final extension of $10 \mathrm{~min}$ at $72{ }^{\circ} \mathrm{C}$. Afterwards, amplicons were purified using the AxyPrep Mag PCR Clean-Up Kit (Axygen, Corning, NY) as per manufacturer's instructions, and the triplicate PCR products per sample were combined. Concentrations of the purified PCR products were determined in duplicate using a Qubit 2.0 Fluorometer (ThermoFisher Scientific, Waltham, MA). These values were used to determine an equal amount of amplicon from each sample for pooling the samples in preparation for sequencing. The pooled purified PCR products were sequenced at the Natural History Museum sequencing facility using an Illumina MiSeq platform (Illumina, San Diego, CA).

\section{$16 \mathrm{~S}$ and $18 \mathrm{~S}$ rRNA gene sequence analysis}

Sequences were demultiplexed based on the Golay barcodes as a pre-processing step within the Illumina MiSeq platform. Illumina data were analysed using QIIME 1.8 (Caporaso et al. 2010). Paired-end reads were merged to obtain fulllength amplicon sequence reads. To identify and remove chimeric sequences from the $16 \mathrm{~S}$ data, the UCHIME algorithm (Edgar 2010; Edgar et al. 2011) was used with the 16S rRNA Greengenes 13_8 database as reference (DeSantis et al. 2006). For 18S, the VSEARCH tool (Rognes et al. 2016) was used alongside the 18 S rRNA Silva 123 database as reference (Pruesse et al. 2007). Operational Taxonomic Units (OTUs) were identified to a threshold of $>97 \%$ similarity to the same reference database. An open-reference picking method was used in OTU picking, whereby reads are clustered against the reference sequence collection and any reads that do not hit the reference database are subsequently clustered de novo. Sequences were then filtered to remove chloroplast and mitochondrial taxonomic units in the $16 \mathrm{~S}$ data, as well as OTUs grouping with metazoan phyla from the 18S data. Metazoan phyla were removed as they are multicellular and bias the relative abundance community analysis. Furthermore, the short 18S rRNA gene reads provide limited taxonomic resolution. Sequences were submitted to the Short Read Archive (Project accession number: SUB7342615).

The alpha_rarefaction.py workflow command in QIIME was used to generate rarefied OTU tables; compute alpha diversity metrics for each rarefied OTU table; collate alpha diversity results; and generate alpha rarefaction plots. All Bacteria and Archaea samples were rarefied to a sampling depth of 136,255 sequences, and eukaryote samples to 4236, since these were the minimum sample depths across all samples. Multiple alpha diversity indices were calculated to overcome the potential bias of any one index. Chao1 and ACE (Abundance-based Coverage Estimate) describe the richness of OTUs in each sample. By adding a correction factor to the observed OTUs, these indices provide estimates of the total number that would be observed with infinite sampling. Simpson's and Shannon's indices were calculated as measures of diversity, accounting for both abundance and evenness of observed OTUs. Good's coverage test was used as a measure of sample coverage, to estimate the percent of the total number of species represented in the samples. Rarefaction curves were plotted in QIIME for the observed species and Chaol estimate to assess sampling coverage of species richness. Relative abundance of taxa in each sample was visualised in $\mathrm{R}$ at phyla and family/genus level for whole Bacteria and Archaea and eukaryote communities, respectively, and at the genus level for Proteobacteria and Cyanobacteria taxa separately.

Variation in community composition between ponds was analysed using non-metric multidimensional scaling (NMDS) for the whole Bacteria and Archaea and eukaryote communities, and for groupings within the Proteobacteria and Cyanobacteria separately. We used metaMDS functions in the "vegan" package in R v 3.6.1 (Dixon 2003; R Core 
Team 2019), to develop Bray-Curtis dissimilarity matrices from OTU tables. The matrices were projected onto $2 \mathrm{D}$ ordination plots and ellipses were drawn for each pond around 95\% confidence intervals using the stat_ellipse() function in "ggplot2". Non-parametric analysis of similarity (ANOSIM) was conducted in $\mathrm{R}$ using Bonferroni-corrected $p$ values, to determine whether Bray-Curtis dissimilarities were significant between ponds at the OTU level. SIMPER non-parametric tests were used to identify the phyla which made the largest contributions to Bray-Curtis dissimilarities between communities in the Bacteria and Archaea, and Eukaryotes. Canonical correspondence analysis (CCA) was used to examine the relationships between the sampled communities and their environment. CCAs were performed using the cca() function in the R package "vegan", with OTU tables and environmental variables which were measured at the time of sampling. An ANOVA-like permutation test was used to assess the significance of constraints in the CCAs (termed anova.cca() in "vegan"). Mantel tests were used to test for correlation between differences in community composition and distance along the sampling transects within each pond using Euclidean distances and 700 permutations. Mantel tests were used to correlate geographic distance between meltwater ponds to community composition of microbial mat samples. Distance matrices for environmental parameters were created using Euclidean distance and geospatial matrices were created using Haversine distance. These were correlated to Bray-Curtis dissimilarity matrices from OTU tables. Mantel tests were based on Spearman's rank correlation with 10,000 permutations and conducted using the "vegan" package in R (Hijmans et al. 2012).

\section{Results}

\section{Environmental conditions of meltwater ponds on the McMurdo Ice Shelf, Antarctica}

The hypersaline Salt Pond had the highest mean conductivity $\left(41,283 \mu \mathrm{S} \mathrm{cm}^{-1}\right)$, and Brack Pond the second highest average $\left(6,073 \mu \mathrm{S} \mathrm{cm}^{-1}\right)$. The other ponds had lower conductivities within in the range of 1,839 to $4,456 \mu \mathrm{S} \mathrm{cm}-1$ (Online Resource 2). pH was highest in Duet Pond (10.8) and lowest in Brack Pond (8.8). Mean temperature of each pond across samples ranged from 1.1 (Duet Pond) to $8.1^{\circ} \mathrm{C}$ (Pond Seventy) (Online Resource 2).

\section{S rRNA and 18S rRNA gene richness and composition in McMurdo Ice Shelf microbial mats}

The total OTU count for the 16S rRNA gene data over the 36 microbial mat samples was $8,624,816$, with a mean count of 239,578. Good's coverage values of species richness confirmed good coverage within the analysis, with a minimum (16S rRNA gene) sample score of 0.973 to 0.993 for ponds. Conophyton Pond microbial mats had the highest OTU richness of Bacteria and Archaea taxa, and the highest mean Bacteria and Archaea diversity. Salt Pond had the lowest Bacteria and Archaea richness (Online Resource 3).

Good's coverage values also indicated good coverage for the eukaryotic 18S gene (Online Resource 4), with minimum sample score for each pond varying from 0.982 to 0.994 . As for Bacteria and Archaea, the highest species richness of eukaryote taxa was in Conophyton Pond mats but the lowest was in Skua. Other ponds clustered between Chaol values of 200-300. Eukaryote diversity was highest in Duet Pond and, like richness, lowest in Skua Pond.

Within the Bacteria and Archaea, at the phylum level, Cyanobacteria and Proteobacteria were dominant (Fig. 3a). Dominance by Cyanobacteria was greatest in the higher salinity Brack and Salt ponds. Bacteroidetes (4\%), Verrucomicrobia $(1 \%)$ and Firmicutes $(0.5 \%)$ were also well represented, and together these five phyla comprised more than $95 \%$ of OTUs across all samples. Cyanobacteria and Proteobacteria made the first and second greatest contributions to Bray-Curtis dissimilarities between Bacteria and Archaea communities at the phylum level across all ponds (Online Resource 5).

Within the Cyanobacteria, 21 families were identified, with Phormidiaceae (16\% of all Cyanobacteria), Nostocaceae (6\%), an unidentified Pseudanabaenales family (6\%), an unidentified Cyanobacteria family (5\%) and Pseudanabaenaceae (4\%) comprising $36 \%$ of Cyanobacteria across all samples (Fig. 3b). Within the more saline ponds (Brack and Salt Ponds), there was a distinct shift from dominance of Cyanobacteria by Phormidiaceae to Pseudanabaenales. Most ponds showed similar Cyanobacteria profiles across samples, though variation between samples was evident at Duet and Conophyton Ponds. More than half of all cyanobacterial OTUs were present in all ponds and all ponds contained representatives of Nostocaceae, Phormidiaceae and Pseudanabaenaceae.

Proteobacteria, the second most abundant phylum, were more diverse than the Cyanobacteria with 130 different families across all samples (Fig. 3c). Half of Proteobacteria OTUs were found in all six ponds. Comamonadaceae were the most abundant (comprising 15\% of Proteobacteria) followed by Rhodobacteraceae $8 \%$ and Xanthomonadaceae $3 \%$. Comamonadaceae were the dominant group in all samples but Salt mats, with Rhodobacteraceae dominating across samples in this pond. In Salt pond mats, there was also an increase in the abundance of the phyla Alteromonadaceae, Marinicellaceae and OM60 which have very low percentage abundance in the other microbial mats. As with 


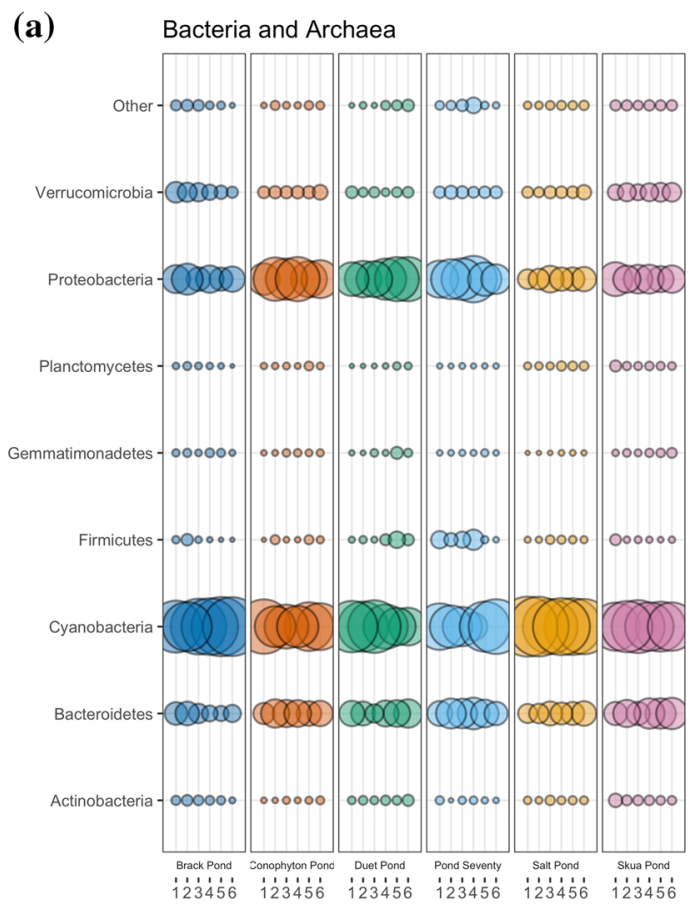

Relative abundance

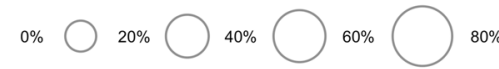

(c)

Proteobacteria

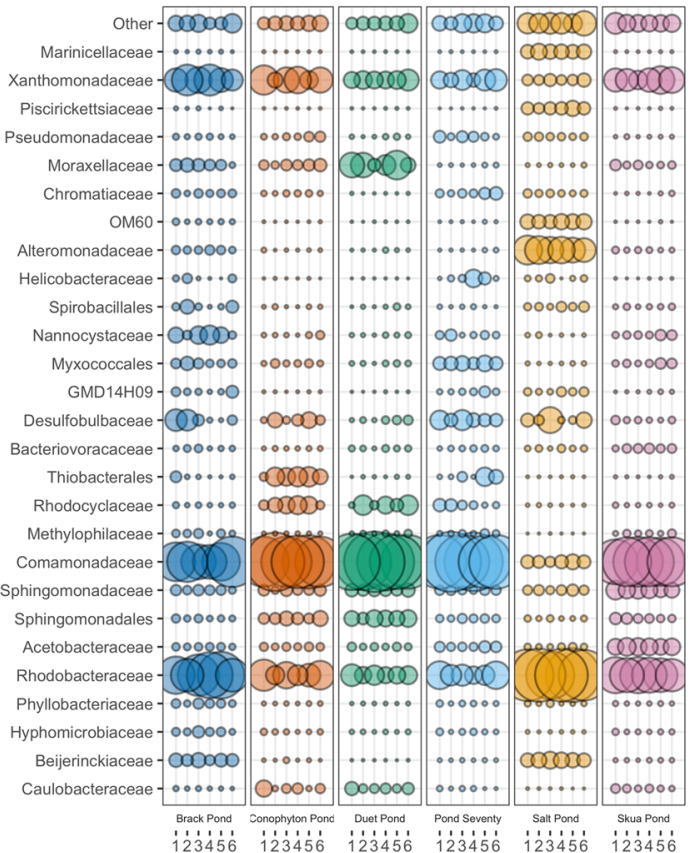

Relative abundance

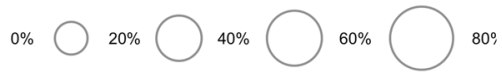

(b)

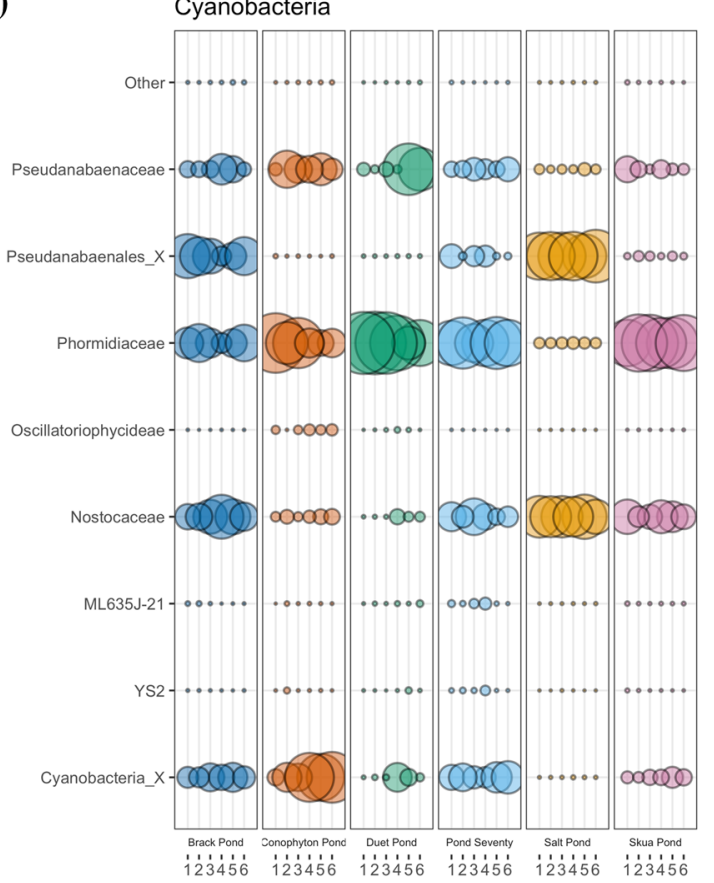

Relative abundance

- ${ }_{0} \%{ }_{20 \%} \bigcirc{ }_{40 \%} \bigcirc{ }_{60 \%} \bigcirc{ }_{80 \%}$

(d)

Eukaryote

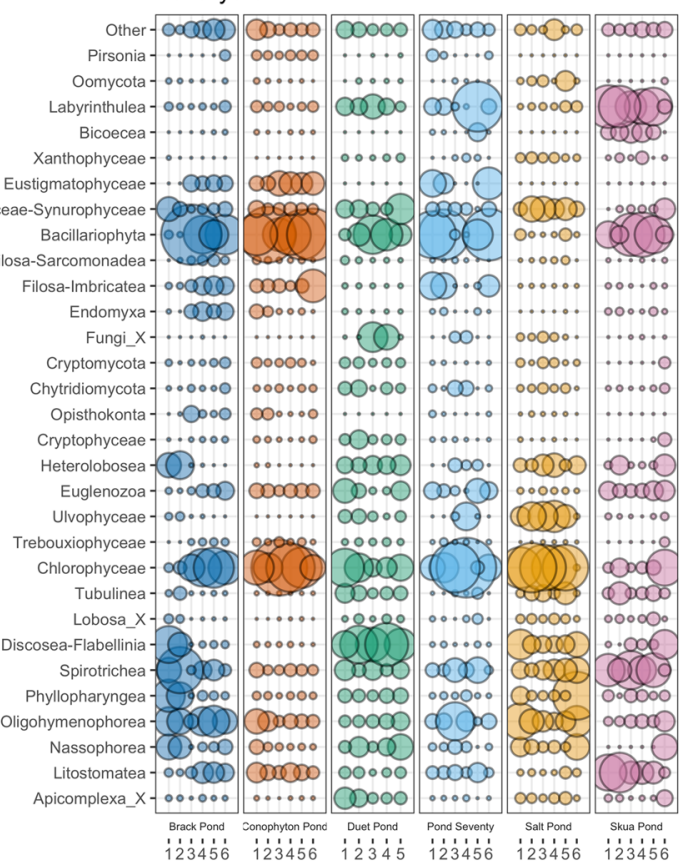

Relative abundance

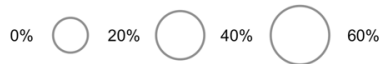


4Fig. 3 Relative abundance (\%) of 16S and 18S rRNA gene microbial mat communities in Duet, Conophyton, Pond Seventy, Brack, Salt and Skua Ponds for a Bacteria and Archaea phyla and families within the b Cyanobacteria, c Proteobacteria and d Eukaryotes. Taxa which comprised less than $0.1 \%$ of total relative abundance for Bacteria and Archaea phyla, $0.01 \%$ for proteobacteria, $0.01 \%$ for Cyanobacteria, and $0.1 \%$ for Eukaryotes were summarised under "other". The area of a dot is proportional to the relative abundance (\%) of a particular taxon as indicated in the legend. For $\mathbf{b}$ and $\mathbf{c}$ percentages are based on taxa within the Cyanobacteria and Proteobacteria only, rather than total relative abundances

Cyanobacteria, within ponds there was a high convergence of Proteobacteria profiles at the family level.

In the Eukaryotes, 24 different phyla were identified following removal of any metazoan OTUs. Bacillariophyta (6.63\%), Chlorophyceae (6.61\%) and Spirotrichea ciliates $(3.41 \%)$ were the dominant groups, together accounting for $15.64 \%$ of eukaryote taxa. While some consistent, pondspecific tendencies were evident, including abundant Bacillariophyta in Conophyton Pond, heterotrophic Labyrinthulea in Skua Pond, and Amoebae (Discosea/Flabellinia) in Duet Pond, the degree of inter-sample difference within lakes appeared much higher for Eukaryotes than Bacteria and Archaea (Fig. 3d). Other families of microalgae included Trebouxiophyceae, Ulvophyceae, Cryptophyceae, Chrysophyceae, Xanthophyceae and Eustigmatophyceae. The 18S rRNA gene communities also comprised fungi and additional heterotrophic protists including several classes of ciliates (Litostomatea, Nassophorea, Oligohymenophorea, Phyllopharyngea) and amoeba (Tubulinea, Lobosa) as well as Heterolobosea, Endomyxa, Oomycota and Pirsonia.

\section{Comparison of $16 \mathrm{~S}$ and $18 \mathrm{~S}$ rRNA gene community across meltwater ponds on the McMurdo ice shelf}

Community composition of Bacteria and Archaea communities at the OTU level were more similar within than between ponds (Fig. 4a). Significant ANOSIM R values were observed for all comparisons except Conophyton-Duet and Brack-Skua Ponds, which overlapped (Online Resource 6). NMDS separated ponds primarily along the first axis approximately corresponding to salinity, ordering from the saline Salt, Brack, Pond Seventy and Skua, Conophyton and finally Duet Ponds, the freshest. Separation on axis 2 tended to primarily separate samples from within ponds. Salt Pond samples were particularly tightly clustered, with Conophyton Pond the least congruent.

Proteobacteria and Cyanobacteria show similar NMDS groupings to total Bacteria and Archaea (Fig. 4b and c). Salt Pond again showed a distinct, tight cluster, separated by Brack Pond from overlapping clusters of the other ponds. ANOSIM showed that Salt and Brack pond separation from all other ponds was significant at $p<0.05$ (Online Resource
6). For Proteobacteria, ANOSIM showed that communities from different ponds were significantly different $(p<0.05$ for all comparisons, Online Resource 7), whereas only some of the Cyanobacteria were significantly different (Online Resource 8). Ordering, again primarily along axis 1 , was similar to previous analyses along the pond salinity gradient. Mantel test analysis found that there was a correlation between distance along the sampling transect and dissimilarities for some of the communities (Online Resource 9), but this was not seen in all ponds or for all taxonomic groups.

Eukaryote communities at the genus level had less discrete groupings according to pond than the 16S rRNA gene taxa (Fig. 5). While a degree of within-pond grouping of samples is evident in the NMDS plots, divergent samples resulted in pond groupings overlapping. These overlaps between pond clusters resulted in fewer significant separations of ponds by overall eukaryote community composition than for Bacteria and Archaea. Eukaryote communities were more similar to each other within Conophyton, Duet and Salt Ponds than to the other ponds. No clear evidence of a salinity-related ordering of ponds was evident in the Eukaryote clustering, with even Salt Pond significantly different only to Conophyton Pond. When Ochrophyta, Chlorophyta and Ciliophora were individually examined, the tendency for pond replicates to cluster, but with occasional highly distinct samples from each preventing statistically significant separation, remains (Online Resource 10). Ochrophyta make the greatest contributions to dissimilarities at the phylum level (25.39\%), closely followed by Chlorophyta (24.58\%), Online Resource 11).

\section{Environmental drivers of community structure}

CCAs were used to examine whether measured environmental variables corresponded with the $16 \mathrm{~S}$ rRNA gene composition (Fig. 6a, CCA-ANOVA: $p<0.001, n=1000$, Online Resource 12), Cyanobacteria (Fig. 6b, $p<0.001, n=1000$ ) and Proteobacteria (Fig. 6c, $p<0.001, \mathrm{n}=1000$ ) and $18 \mathrm{~S}$ rRNA gene community (Fig. $7, p<0.001, n=1000$ ). For the prokaryote community, the first and second CCA axis together explained $38 \%$ of the total community variability amongst all the samples. A separation of Salt (and Brack) ponds from all others corresponded to the conductivity vector. Other pond communities were less clearly ordered along the conductivity vector and showed a weaker correspondence with $\mathrm{pH}$ and temperature vectors. For Bacteria and Archaea, constraints explained $25 \%$ of total variation in the dataset.

The results from our Mantel tests supported our CCA results. There were strong relationships between Bacteria and Archaea communities, and the measured environmental parameters (Online Resource 13). As samples became more dissimilar in terms of temperature, $\mathrm{pH}$ and conductivity, they 
Fig. 4 NMDS ordination plots for a prokaryote community composition for absolute counts of OTUs (stress $=0.09, R^{2}=0.992$ ); $\mathbf{b}$ Cyanobacteria (stress $=0.10, R^{2}=0.989$ ); c Proteobacteria only (stress $=0.05, R^{2}=0.997$ ). Points indicate the NMDS scores of individual samples and colour denotes pond. Ellipses are drawn around 95\% confidence intervals

also became more dissimilar in terms of microbial community composition. This effect was strongest for conductivity. Relationships between environmental parameters and community composition were lower for Eukaryote communities than for the Bacteria and Archaea (Online Resource 13). Relationships between the community composition of microbial mats, and distance along the transect within ponds, were less clear, with fewer significant correlations.

\section{Discussion}

In this study, we describe Bacteria, Archaea and eukaryote assemblages in microbial mat communities that dominate the biomass in ponds on the MIS. We examine within- and between-pond variability and produce the first $18 \mathrm{~S}$ rRNA gene high-throughput sequencing report for the McMurdo Ice Shelf, Antarctica. We use these data to investigate how changes in mat community assembly could be related to environmental conditions, in particular salinity. These observations help us to gain a better understanding of assembly processes in microbial mats on the McMurdo Ice Shelf, Antarctica, and to understand the consequences of changes in environmental conditions to the maintenance of microbial biodiversity.

\section{Distinct 165 and 185 rRNA gene microbial communities along a salinity gradient}

The Bacteria and Archaea components were dominated by Cyanobacteria and Proteobacteria, which agrees with previous studies on polar microbial mats using 16S rRNA gene surveys and metagenomics (Varin et al. 2010; Kleinteich et al. 2017; Dillon et al. 2020a, b). There was considerable overlap between ponds at a family level and approximately half of the OTUs in each of these dominant phyla were common to all ponds. However, when analysed as an assemblage, both Cyanobacteria and Proteobacteria communities in individual ponds were quite distinct, with much higher between-pond than within-pond variability, and there was a consistent ordering of the ponds along what appears to be a conductivity gradient. The Salt Pond community was most distinct, which can be attributed to the challenge imposed by extreme high conductivity due to near saturation with sodium sulphate (Wait et al. 2006). Duet Pond's distinct communities, and its exceptionally high $\mathrm{pH}$ and low (a) Bacteria and Archaea

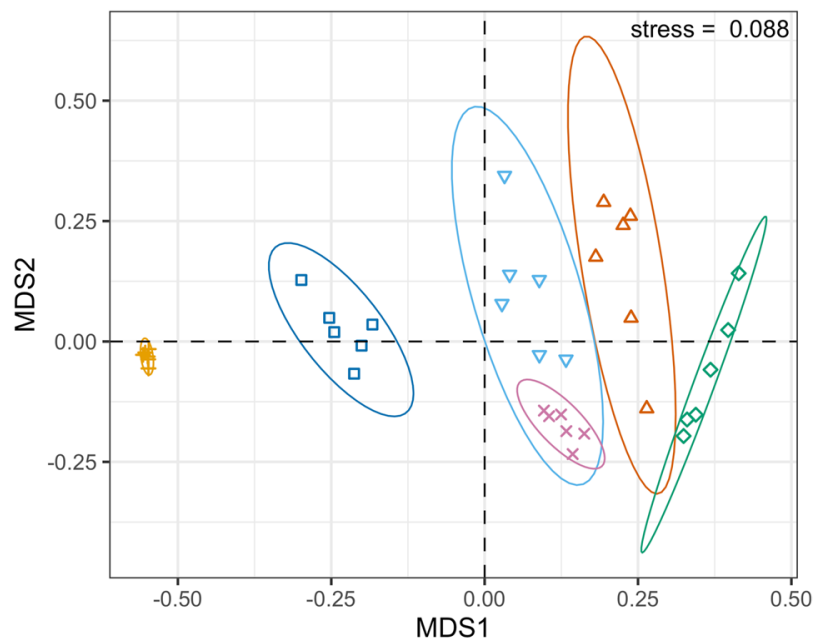

(b) Cyanobacteria

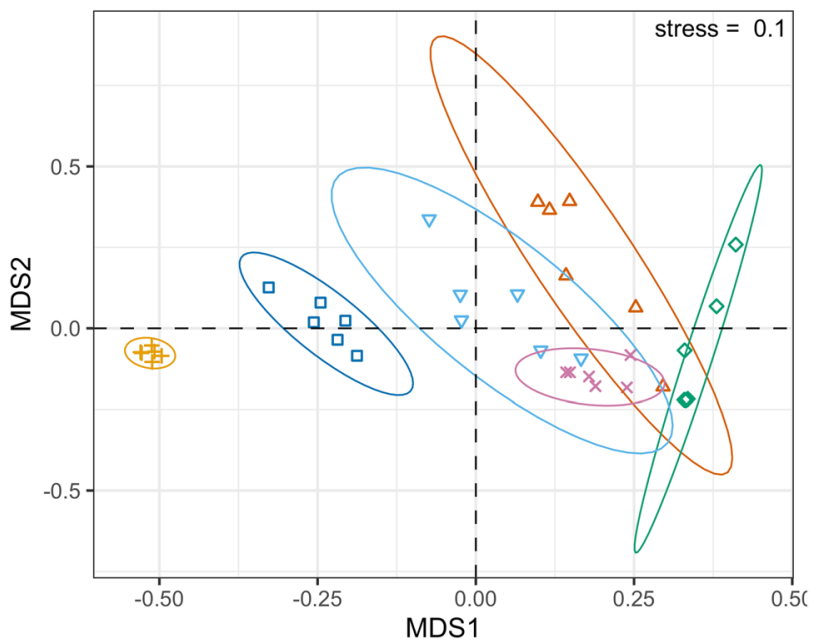

(c) Proteobacteria

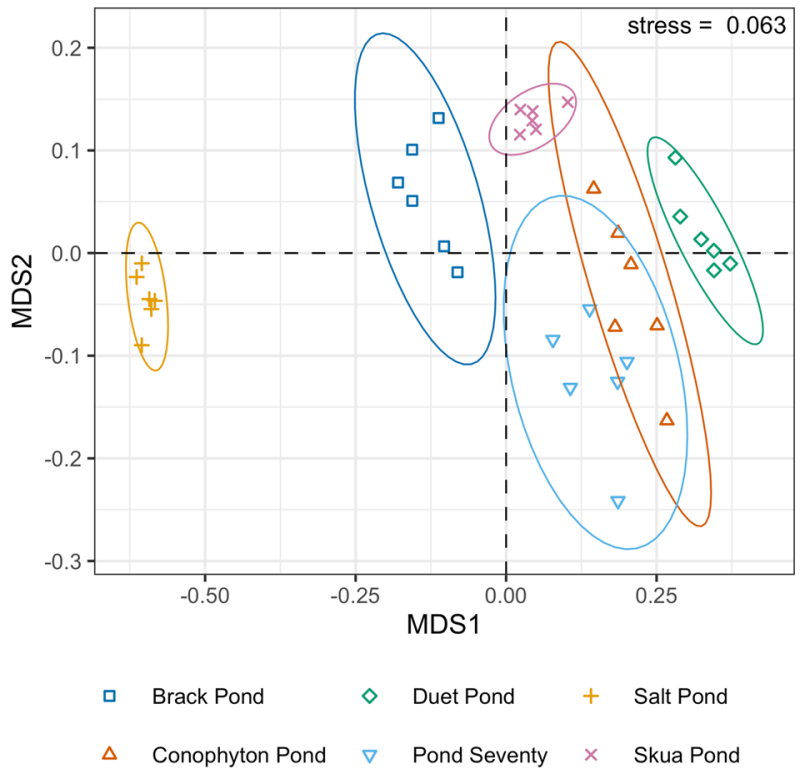




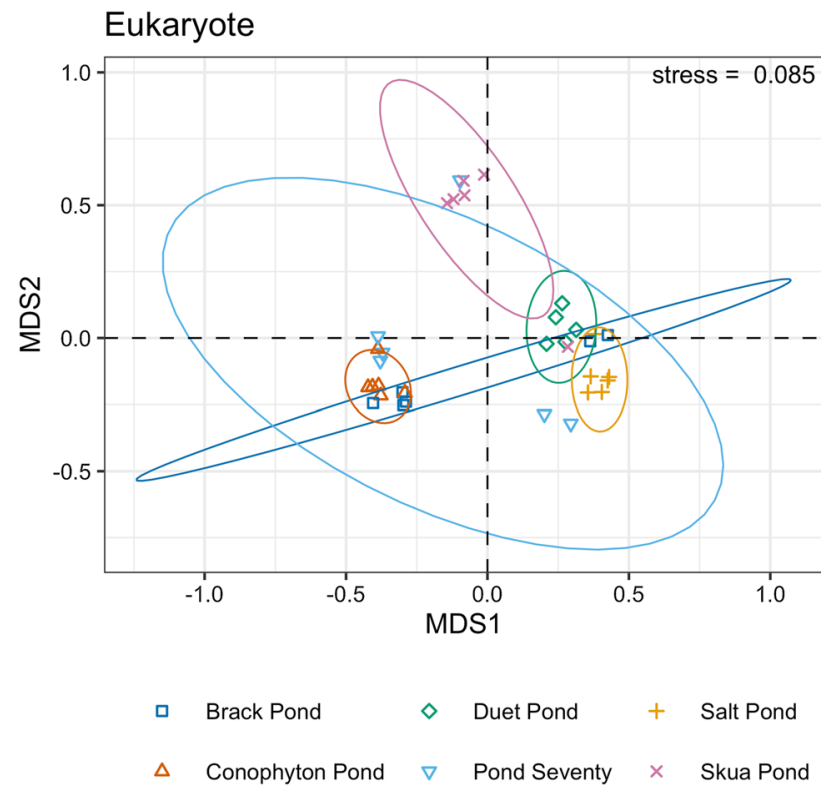

Fig. 5 NMDS ordination plot of eukaryote community composition for absolute counts of OTUs (stress $=0.08, R^{2}=0.993$ ). Points indicate the NMDS scores of individual samples and colour denotes pond. Ellipses are drawn around 95\% confidence intervals

temperature, may reflect the fact that it differs from all of the others in having perennial ice cover. Summer ice cover explains both the high $\mathrm{pH}$ (through photosynthetic $\mathrm{CO}_{2}$ and $\mathrm{HCO}_{3}{ }^{-}$depletion in the absence of atmospheric gas exchange) and its low temperature. Sutherland et al. (2020) also found that ice-covered ponds had particularly distinct diatom communities to those with open water, which they also suggested could be related to the requirement for tolerance of a mix of high $\mathrm{pH}$, low irradiance and temperature. Low OTU richness, diversity and high evenness in both Salt and Duet Ponds are also consistent with increased filtering under these more extreme environmental conditions. A previous study of sediment and bacterioplankton in meltwater ponds on the McMurdo Ice Shelf also identified conductivity and $\mathrm{pH}$ as dominant correlates of the composition of communities. The authors found a correlation with the geochemical composition of the ponds such nitrite $\left(\mathrm{NO}_{2}\right)$, silver (Ag109) and vanadium (V51) (Archer et al. 2014). In a nutrient amendment experiment using a combination of $16 \mathrm{~S}$ rRNA gene sequencing, morphological and pigment analyses, Kohler et al. (2016) showed how enrichment of sodium nitrate and potassium phosphate can affect Cyanobacteria, diatoms and Bacteroides in microbial mats from streams in the McMurdo Dry Valleys. Chemical composition of the meltwater ponds was not assessed in the current study but may account for some of the unexplained variation in communities between ponds.

Cyanobacteria form the structural matrix of microbial mats and, as we found here, it is common to find them dominated by trichomatous, motile genera such as Leptolyngbya, Phormidium and Oscillatoria (Sumner et al. 2016; Jungblut and Vincent 2017). Nitrogen fixation by microorganisms is an important source of nitrogen for MIS ponds (Fernandez-Valiente et al. 2001; Jungblut and Neilan 2010a), where nitrate concentrations are low, but phosphate is abundant (Hawes et al. 2014). Fernandez-Valiente noted that $\mathrm{N}$-fixation was found in ponds across a wide range of salinities, and universal $\mathrm{N}$-fixation was implicated in our study by the considerable abundance of Nostocaceae (Nodularia and Nostoc) in all samples, with all Nostocaceae OTUs found in all ponds. There was a consistent change in dominance within Nostocales from Nostoc spp. in low conductivity ponds to Nodularia spp. at high salinity, but the ability of all to persist implies either broad tolerance about distinct conductivity optima or frequent recolonisation and/ or diapause. Previous work suggested that the Nodularia on the McMurdo Ice Shelf were similar to $N$. spumigena and $N$. haveyana genus (Jungblut et al. 2005), which are well adapted to growth in brackish water, with varying salinity (Lyra et al. 2005; Voss et al. 2013). The Nodularia on the McMurdo Ice Shelf might therefore be better adapted to salt stress than Nostoc, and a shift from Nostoc to Nodularia may therefore be due to environmental filtering. It suggests the potential for functional resilience to changing conductivity in mats by acclimation of community composition while maintaining key function of nitrogen-fixation. Likewise, the presence of a diversity of Oscillatoriales across all ponds, with different organisms dominating mats under different environmental conditions, could imply a reservoir of organisms capable of performing optimally at a range of salt conditions, creating high potential resilience of the mat-forming habit to environmental change.

Proteobacteria assemblages were even more distinct across ponds than Cyanobacteria. Salt Pond was particularly distinct and coherent. The Proteobacteria were dominated by the Comamonadaceae, a metabolically diverse group of mostly motile members of the Betaproteobacteria class. Alteromonadaceae, a mostly marine family of aerobic decomposers, and Rhodobacteraceae displaced Comamonadaceae with increasing conductivity and were particularly abundant in Salt Pond. This might be explained by their affinity for high salt and sulphate concentrations. Previous studies on the MIS ponds also found Proteobacteria to be the dominant phylum in bacterial benthic communities (Archer et al. 2015). As with our study, Archer et al. (2014) found the lowest Proteobacteria diversity was in Salt Pond and communities in Salt Pond were unique compared to all other ponds. The low relative abundance of Archaea agrees with previous works on ice shelf and terrestrial meltwater ponds using metagenomics and amplicon sequencing (Varin et al. 2010, 2012; Archer et al. 2014). The present study also found taxa from the order Methanomicrobiales 
Fig. 6 CCA of a prokaryote community composition for absolute counts of OTUs, b Cyanobacteria and $\mathbf{c}$ Proteobacteria. Each point represents a single sample. Vectors show environmental variables (temperature $\left({ }^{\circ} \mathrm{C}\right), \mathrm{pH}$ and conductivity $\left(\mu \mathrm{S} \mathrm{cm} \mathrm{cm}^{-1}\right)$ which were measured at the time of sampling, with arrowheads indicating their direction of increase

(family Methanosarcinaceae). However, universal $16 \mathrm{~S}$ rRNA gene primers might be less well suited to cover all archaeal groups, and these may be under-reported (Parada et al. 2016).

Our study is the first detailed 18S rRNA gene highthroughput sequencing analysis of microbial mats on the McMurdo Ice Shelf. The 18S rRNA gene analysis suggested that microbial Eukaryotes had a lower richness than the Bacteria and Archaea, which was also found for microbial mats in the perennially ice-covered Lake Untersee and Lake Fryxell, Antarctica (Greco et al. 2020), and been described from other ecosystems such as cryoconite holes in the McMurdo Dry Valleys (Sommers et al. 2018). The communities were dominated by Ochrophyta, Chlorophyta and Ciliophora, and previous work on 18S rRNA gene clone library and morphological surveys had demonstrated that microalgae, especially diatoms, are present in meltwater ponds (Sutherland 2009; Jungblut et al. 2012b). Sommers et al. (2018) and Greco et al. (2020) also found abundance of ciliates and similar groups of ciliates in Lake Untersee and cryoconite holes from Taylor Valley glaciers; however, it appears that more ciliate $18 \mathrm{~S}$ rRNA gene sequences were recovered from microbial mats on the McMurdo Ice shelf. In contrast, fungi had a lower relative abundance on the McMurdo Ice Shelf and cryoconite holes than in the microbial mats in the ice-covered Lake Untersee. Our studies also identified the presence of a wide range of other heterotrophic protist taxa grouping within Rhizaria, Labyrinthulea, Excavata and Amoeba. The pond eukaryote communities varied in their assemblages within and across ponds which meant that few ponds had significantly different assemblages. There was also no consistency in clustering within different taxonomic groups and little evidence of consistent ordering along the environmental gradients that were measured. Broad tolerances for the range of conditions, biotic and abiotic, provided by the ponds are implied. Our study did not find the same strong correlation between Bacteria and Eukaryotes as described for ice-lidded cryoconite hole microbial communities in the McMurdo Dry Valleys (Sommers et al. 2018).

\section{S rRNA gene and 18S rRNA gene microbial assembly processes in microbial mats on the McMurdo Ice Shelf}

Our study identified high within-pond congruity in Bacteria and Archaea communities that could suggest the (a) Bacteria and Archaea

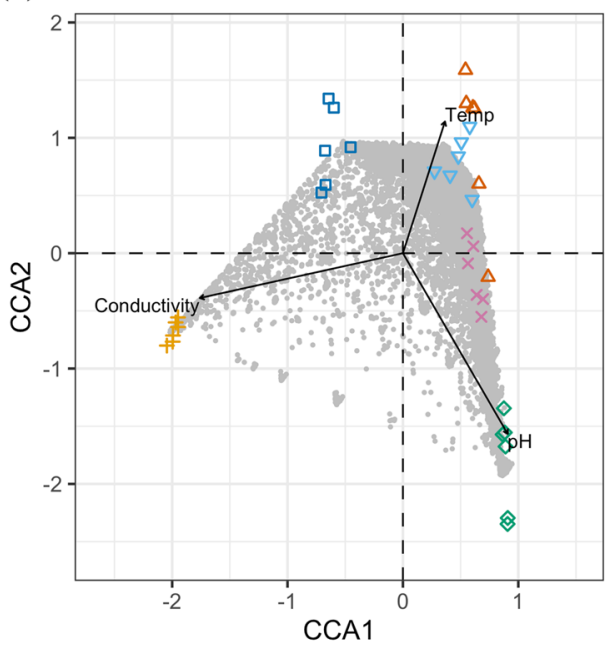

(b) Cyanobacteria

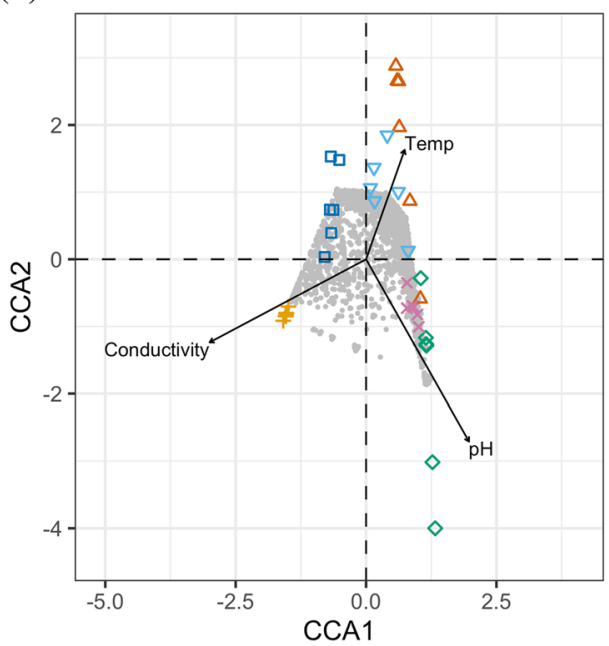

(c) Proteobacteria

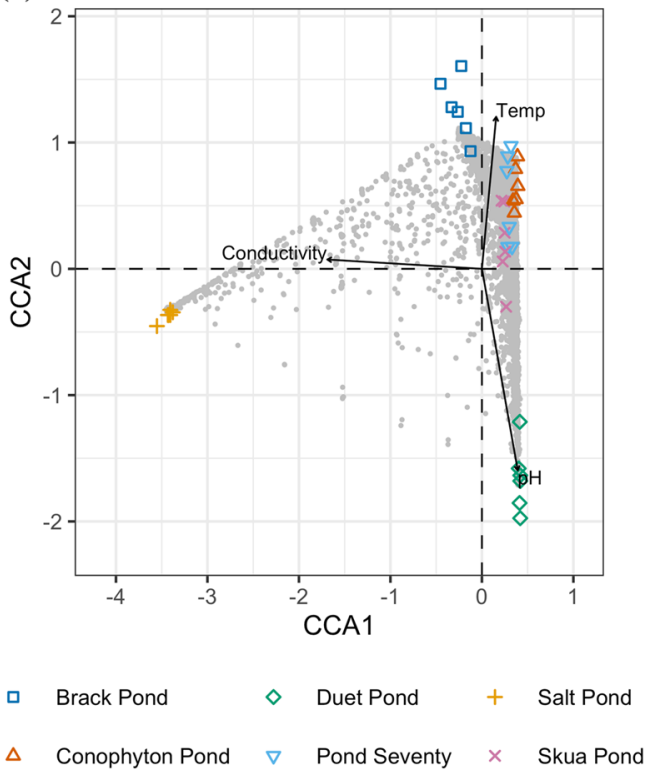



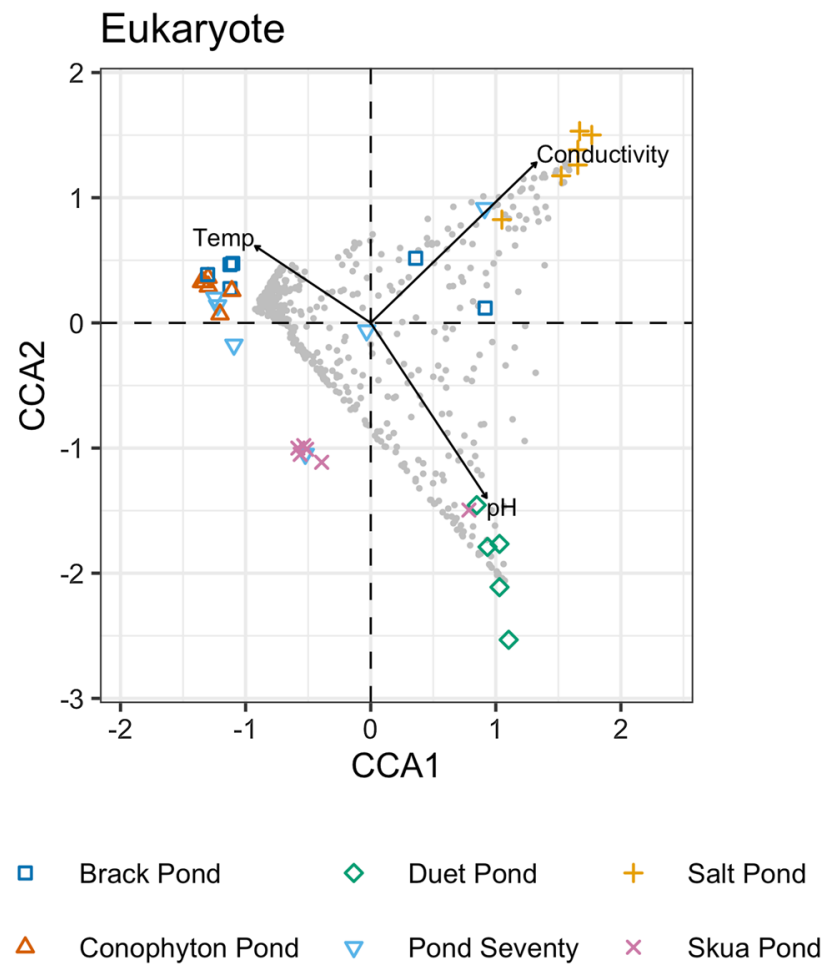

Fig. 7 CCA of eukaryote community composition for absolute counts of OTUs. Each point represents a single sample. Vectors show environmental variables (temperature $\left({ }^{\circ} \mathrm{C}\right), \mathrm{pH}$ and conductivity $(\mu \mathrm{S}$ $\left.\mathrm{cm}^{-1}\right)$ ), which were measured at the time of sampling, with arrowheads indicating their direction of increase

environmental conditions within these ponds lead to habitat filtering, providing support for homogenous microbial mat assemblies. Microbial mats accumulate over many years and there are relatively few disturbance processes that could provide opportunities for colonisation and succession, and thereby introduce spatial variability. Physical disturbance is limited to exposure to wind abrasion following a decline in water level (Hawes et al. 2014) and "liftoff events" as described by Wharton et al. (1983). Lift-off occurs when mats accumulate sufficient gas bubbles for buoyancy to exceed tensile strength, allowing mats to tear off the pond sediment and float to the surface (authors' observations). The frequency and extent of disturbance is poorly constrained in these ponds, but recovery from liftoff events will require full or partial regrowth of microbial mats on the newly exposed pond sediments. We anticipated that disturbance events would create diversity within ponds where colonisation and succession were necessary to build a mature mat structure. Within each of the ponds, we observed that there was limited correlation between community dissimilarity and separation distance within any of the studied meltwater ponds. The simplest explanations of this are that disturbance is infrequent and/or any stochastic effect in recolonisation of newly exposed pond sediment is dominated by the high biomass of the resident organisms (Shea et al. 2012) or residual populations within the lift-off scar. In this scenario, long-term environmental filtering is sustained over time by the high probability of existing taxa occupying newly exposed substrate, but with any directional change, in e.g. conductivity, gradually moving composition towards a new normal. Neutral processes (Hubbell 2008) can prevail when sympatric species show a high degree of ecological convergence, which reduces the selection power of nichedriven processes and allows dispersal, chance and survival to play significant roles in determining composition. However, despite the presence of multiple taxa potentially capable of forming functional mats within each pond, evidenced by the shared diversity of filamentous Oscillatoriales, different subsets of which dominate mat formation in different ponds, high levels of stochastic within-pond variation are not evident. This we suggest implies sufficient niche separation between bacterial taxa to allow ponds to develop distinct assemblages over time.

The assembly of microbial Eukaryotes within the ponds also provides some evidence of niche-driven processes with within-pond communities showing more resemblance than between-pond communities. However, measured environmental variables show limited capacity to explain the dissimilarities between ponds. A comprehensive study on diatoms using microscopic species identification by Sakaeva et al. (2016) of terrestrial ponds on Ross Island and McMurdo Dry Valleys suggested that chemistry and the type and composition of the microbial mat may play a role at local scale while geography, dispersal and historical environmental conditions influence structuring of diatom assemblages across larger spatial scales. Sutherland (2009) and Sutherland et al. (2020) similarly noted that many diatom morphospecies were widely distributed across ponds of a wide range of salinities on the MIS, and suggest broad habitat tolerance and/ or dispersal ability. James et al. (1995) using microscopybased identification reported that between-pond distinction of planktonic protist populations was best explained by pond size rather than salinity. The implication is of considerably greater overall niche convergence amongst eukaryotic protists, and a wide physiological tolerance to salinity, though a wider range of potentially explaining variables would need to be examined to confirm the former. We suggest that a low biomass of microbial Eukaryotes in the MIS ponds in connection with greater mobility and greater overlap of optimal conditions amongst taxa may allow for stochastic processes to have a greater effect on community assembly for Eukaryotes than Bacteria and Archaea.

There are additional community assembly theories such as the island species-area relationships (MacArthur and Wilson 1967) which describes the macroecological pattern of an increase in number of species with an increase in area of an island. Sommers et al. 2020 showed that relationship 
between 16S rRNA gene and 18S rRNA gene communities in cryoconites from glaciers in the McMurdo Dry Valleys can be explained by the species-area theory. However, comparison of the area of meltwater ponds in our study based on personal observations of sampling sites by the authors and approximate sizes provided in Fig. 2 with determined $16 \mathrm{~S}$ and 18S rRNA gene OTUs richness (Online Resource 3 ) suggests that there is not a clear link between area of meltwater ponds and number of species. The highest richness was found in Conophyton Pond, which was one of the smaller ponds, and Duet Pond with the largest area had the median richness, with Salt Pond being of medium size having the lowest richness. However, a larger number of samples and bigger range of habitat areas would be needed to be able to apply the mathematical model as done in the study by Sommers et al. (2020).

\section{Conclusions}

We present an in-depth characterisation of Bacteria and Archaea and microbial Eukaryote communities in microbial mats in meltwater ponds of the McMurdo Ice Shelf, Antarctica. Diverse populations were observed in all ponds and Bacteria and Archaea assemblages were highly pondspecific and appear to order along environmental gradients. Eukaryotes were less diverse than Bacteria and Archaea and were also characterised by less between-pond dissimilarity. These findings will help to understand processes that are important in sustaining biodiversity in ice-based habitats, especially in Antarctica, with potential acceleration of environmental change that may accompany polar warming.

Supplementary Information The online version contains supplementary material available at https://doi.org/10.1007/s00300-021-02843-2.

Acknowledgements Logistical support was provided by Antarctica New Zealand, and field assistance was provided by Maria Monteiro (Waikato University, NZ) and Phil Clunies-Ross (Canterbury University, NZ). We thank Doko Miles Thorburn who helped with the molecular analysis, and the Scott Base staff for support and use of facilities, as well as the Drs Rachel Morgan-Kiss and Lee Stanish and an anonymous Reviewer for their insightful comments and suggestions.

Authors' contributions ADJ and IH designed the study and collected the samples; EJ performed sample processing, sequencing and statistical analysis. All three authors contributed to the writing of the manuscript.

Funding Logistical support was provided by Antarctica New Zealand.

Data availability The sequences generated during the current study are available in the Short Read Archive (Project accession number: SUB7342615).

\section{Declarations}

Conflict of interest The authors declare that they have no conflict of interest.

Ethical approval Not applicable.

Consent for publication Not applicable.

Open Access This article is licensed under a Creative Commons Attribution 4.0 International License, which permits use, sharing, adaptation, distribution and reproduction in any medium or format, as long as you give appropriate credit to the original author(s) and the source, provide a link to the Creative Commons licence, and indicate if changes were made. The images or other third party material in this article are included in the article's Creative Commons licence, unless indicated otherwise in a credit line to the material. If material is not included in the article's Creative Commons licence and your intended use is not permitted by statutory regulation or exceeds the permitted use, you will need to obtain permission directly from the copyright holder. To view a copy of this licence, visit http://creativecommons.org/licenses/by/4.0/.

\section{References}

Amaral-Zettler LA, McCliment EA, Ducklow HW, Huse SM (2009) A Method for Studying Protistan Diversity Using Massively Parallel Sequencing of V9 Hypervariable Regions of Small-Subunit Ribosomal RNA Genes. PLoS ONE 4:e6372

Archer S, McDonald I, Herbold CW, Cary SC (2014) Characterisation of bacterioplankton communities in the meltwater ponds of Bratina Island, Victoria Land, Antarctica. FEMS Microbiol Ecol 89:451-464

Archer S, Herbold CW, McDonald I, Lee C, Cary SC (2015) Benthic microbial communities of coastal terrestrial and ice shelf Antarctic meltwater ponds. Front Microbiol 6:485

Armitage DW, Gallagher KL, Youngblut ND, Buckley DH, Zinder SH (2012) Millimeter-scale patterns of phylogenetic and trait diversity in a saltmarsh microbial mat. Front Microbiol 3:293

Caporaso JG, Kuczynski J, Stombaugh J, Bittinger K, Bushman FD, Costello EK et al (2010) QIIME allows analysis of high-throughput community sequencing data. Nat Methods 7:335-336

Caporaso JG, Lauber CL, Walters WA, Berg-Lyons D, Lozupone CA, Turnbaugh PJ et al (2011) Global patterns of 16S rRNA diversity at a depth of millions of sequences per sample. Proc Natl Acad Sci 108:4516-4522

Caporaso JG, Lauber CL, Walters WA, Berg-Lyons D, Huntley J, Fierer N et al (2012) Ultra-high-throughput microbial community analysis on the Illumina HiSeq and MiSeq platforms. ISME J 6:1621-1624

Cowan DA, Tow LA (2004) Endangered Antarctic Environments. An Rev Microbiol 58:649-690

De Los RA, Ascaso C, Wierzchos J, Fernández-Valiente E, Quesada A (2004) Microstructural characterization of cyanobacterial mats from the McMurdo Ice Shelf, Antarctica. Appl Environ Microbiol 70:569-580

De Mora SJ, Whitehead R, Gregory M (1994) The chemical composition of glacial melt water ponds and streams on the McMurdo Ice Shelf, Antarctica. Antarc Sci 6:17-27

DeSantis TZ, Hugenholtz P, Larsen N, Rojas M, Brodie E, Keller K et al (2006) Greengenes, a Chimera-Checked 16S rRNA Gene

Code availability Not applicable. 
Database and Workbench Compatible with ARB. Appl Environ Microbiol 72:5069-5072

Dillon ML, Hawes I, Jungblut AD, Mackey TJ, Eisen JA, Doran PT, Sumner DY (2020a) Environmental control on the distribution of metabolic strategies of benthic microbial mats in Lake Fryxell. Antarctica PLOS One 15:e0231053. https://doi.org/10.1371/journ al.pone. 0231053

Dillon ML, Hawes I, Jungblut AD, Mackey TJ, Eisen JA, Doran PT, Sumner DY (2020b) Energetic and environmental constraints on the community structure of benthic microbial mats in lake fryxell. Antarctica FEMS Microbiology Ecology 96:2

Dixon P (2003) VEGAN, a package of R functions for community ecology. J Veg Sci 14:927-930

Edgar RC (2010) Search and clustering orders of magnitude faster than BLAST. Bioinformatics 26:2460-2461

Edgar RC, Haas BJ, Clemente JC, Quince C, Knight R (2011) UCHIME improves sensitivity and speed of chimera detection. Bioinformatics 27:2194-2200

Fernandez-Valiente E, Quesada A, Howard-Williams C, Hawes I (2001) $\mathrm{N}_{2}$-Fixation in cyanobacterial mats from ponds on the McMurdo Ice Shelf, Antarctica. Microb Ecol 42:338-349

Greco C, Andersen DT, Hawes I, Bowles AMC, Yallop ML, Barker G, Jungblut AD (2020) Microbial diversity of pinnacle and conical microbial mats in the perennially ice-covered Lake Untersee East Antarctica. Front Microbiol. https://doi.org/10.3389/fmicb. 2020.607251

Hawes I, Safi K, Sorrell B, Webster-Brown J, Arscott D (2011) Summer-winter transitions in Antarctic ponds: I. The physical environment Antarc Sci 23:235-242. https://doi.org/10.1017/ S0954102011000046

Hawes I, Howard-Williams C, Sorrell B (2014) Decadal timescale of variability in ecosystem properties in the ponds of the McMurdo Ice Shelf, Southern Victoria Land, Antarctica. Antarc Sci 26:219-230

Hawes I, Jungblut AD, Matys ED, Summons RE (2018) The "Dirty Ice" of the McMurdo Ice Shelf: Analogues for biological oases during the Cryogenian. Geobiol 16:369-377

Hawes I, Sumner D, Jungblut AD (2019) complex structure but simple function in microbial mats from antarctic lakes. In: Hurst CJ (ed) Advances in environmental microbiology. Springer International Publishing, Cham, pp 90-120

Hijmans RJ, Williams E, Vennes C (2012) Geosphere: spherical trigonometry, R Package version 1-2

Howard-Williams C, Pridmore R, Downes MT, Vincent WF (1989) Microbial biomass, photosynthesis and chlorophyll a related pigments in the ponds of the McMurdo Ice Shelf, Antarctica. Antarc Sci 1:125-131

Howard-Williams C, Pridmore R, Broady P, Vincent WF (1990a) Environmental and biological variability in the McMurdo Ice Shelf ecosystem. In: Kerry K, Hempel G (eds) Antarctic ecosystems. Ecological change and conservation. Springer Verlag, Berlin, Heidelberg

Howard-Williams C, Pridmore RD, Broady PA, Vincent WF (1990b) Environmental and biological variability in the McMurdo Ice Shelf ecosystem. In: Kerry KR (ed) Antarctic Ecosystems. Springer, Berlin, pp 23-31

Hubbell SP (2008) Approaching tropical forest complexity, and ecological complexity in general, from the perspective of symmetric neutral theory. In: Carson W, Schnitzer S (eds) Tropical forest community ecology. Wiley-Blackwell, Oxford, pp 143-159

James MR, Pridmore RD, Cummings VJ (1995) Planktonic communities of melt ponds on the McMurdo Ice Shelf, Antarctica. Polar Biol 15:555-567

Jungblut AD, Neilan BA (2010a) NifH gene diversity and expression in a microbial mat community on the McMurdo Ice Shelf, Antarctica. Antarc Sci 22:117-117
Jungblut AD, Neilan BA (2010b) Cyanobacteria mats of the meltwater ponds on the McMurdo Ice Shelf (Antarctica). In: Seckbach J, Oren S (eds) Cellular Origins. Springer-Verlag, Life in Extreme Habitats and Astrobiology, pp 499-414

Jungblut AD, Vincent WF (2017) Cyanobacteria in polar and alpine ecosystems. In: Margesin R (ed) Psychrophiles: from biodiversity to biotechnology. Springer, Heidelberg, pp 181-206

Jungblut AD, Hawes I, Mountfort D, Hitzfeld B, Dietrich DR, Burns BP et al (2005) Diversity within cyanobacterial mat communities in variable salinity meltwater ponds of McMurdo Ice Shelf, Antarctica. Environ Microbiol 7:519-529

Jungblut AD, Wood SA, Hawes I, Webster-Brown J, Harris C (2012a) The pyramid trough wetland: environmental and biological diversity in a newly created Antarctic protected area. FEMS Microbiol Ecol 82:356-366

Jungblut AD, Vincent WF, Lovejoy C (2012b) Eukaryotes in Arctic and Antarctic Cyanobacterial mats. FEMS Microbiol Ecol 82:416-428

Jungblut AD, Hawes I, Mackey TJ, Krusor M, Doran PT, Sumner DY et al (2016) Microbial mat communities along an oxygen gradient in a perennially ice-covered Antarctic lake. Appl Environ Microbiol 82:620-630

Kennicutt MC, Chown SL, Cassano JJ, Liggett D, Massom R, Peck LS et al (2014) Polar research: Six priorities for Antarctic science. Nature 512:23-25

Kleinteich J, Hildebrand F, Bahram M, Voigt AY, Wood SA, Jungblut AD, Küpper FC, Quesada A, Camacho A, Pearce DA, Convey P, Vincent WF, Zarfl C, Bork P, Dietrich DR (2017) Pole-to-Pole connections: Similarities between arctic and antarctic microbiomes and their vulnerability to environmental change. Frontiers Ecol Evol. https://doi.org/10.3389/fevo.2017.00137

Kohler TJ, Van Horn DJ, Darling JP, Takacs-Vesbach CD, McKnight DM (2016) Nutrient treatments alter microbial mat colonization in two glacial meltwater streams from the McMurdo Dry Valleys. Antarctica FEMS Microbiology Ecology 92:4. https://doi.org/10. 1093/femsec/fiw049

Leibold MA, Chase JM (2018) The theories of metacommunities. In: Leibold MA, Chase JM (eds) Metacommunity Ecology. Princeton University Press, Princeton

Lyons WB, Welch KA, Gardner CB, Jaros C, Moorhead DL, Knoepfle JL et al (2012) The geochemistry of upland ponds, Taylor Valley, Antarctica. Antarc Sci 24:3-14

Lyra C, Laamanen M, Lehtimäki JM, Surakka A, Sivonen K (2005) Benthic Cyanobacteria of the genus Nodularia are non-toxic, without gas vacuoles, able to glide and genetically more diverse than planktonic Nodularia. Int J Syst Evol Microbiol. https://doi.org/ 10.1099/ijs.0.63288-0

MacArthur RH, Wilson EO (1967) The theory of island biogeography. Princeton, Princeton University Press

Parada AE, Needham DM, Fuhrman JA (2016) Every base matters: Assessing small subunit rRNA primers for marine microbiomes with mock communities, time series and global field samples. Environ Microbiol 18:1403-1414

Pörtner HO, Roberts DC, Masson-Delmotte V, Zhai P, Tignor M, Poloczanska E, Mintenbeck K, Nicolai M, Okem A, Petzold J, Rama B (2019) IPCC special report on the ocean and cryosphere in a changing climate. IPCC Intergovernmental Panel on Climate Change: Geneva, Switzerland 1:3

Pruesse E, Quast C, Knittel K, Fuchs BM, Ludwig W, Peplies J et al (2007) SILVA: a comprehensive online resource for quality checked and aligned ribosomal RNA sequence data compatible with ARB. Nucleic Acids Res 35:7188-7196

R Core Team (2019) R: A language and environment for statistical computing. R Foundation for Statistical Computing, Vienna, Austria

Rognes T, Flouri T, Nichols B, Quince C, Mahé F (2016) VSEARCH: a versatile open source tool for metagenomics. PeerJournal 4:e2584 
Rosindell J, Hubbell SP, Etienne RS (2011) The unified neutral theory of biodiversity and biogeography at age ten. Trends Ecol Evol 26:340-348

Sakaeva A, Sokol ER, Kohler TJ, Stanish LF, Spaulding SA, Howkins A, Welch KA, Lyons WB, Barrett JE, Mcknight DM (2016) Evidence for dispersal and habitat controls on pond diatom communities from the McMurdo Sound Region of Antarctica. Polar Biol 39(12):2441-2456

Schneider D, Arp G, Reimer A, Reitner J, Daniel R (2013) Phylogenetic analysis of a microbialite-forming microbial mat from a hypersaline lake of the Kiritimati atoll. Central Pacific PLoS One 8:e6662

Shea K, Chesson P (2012) Community ecology theory as a framework for biological invasions. Trends Ecol Evol 17:170-176

Sommers P, Darcy JL, Gendron EMS, Stanish LF, Bagshaw EA, Porazinska DL, Schmidt SK (2018) Diversity patterns of microbial Eukaryotes mirror those of Bacteria in Antarctic cryoconite holes. FEMS Microbiol Ecol 94:1. https://doi.org/10.1093/femsec/ fix 167

Sommers P, Porazinska DL, Darcy JL, Gendron EMS, Vimercati L, Solon AJ, Schmidt SK (2020) Microbial species-area relationships in Antarctic cryoconite holes depend on productivity. Microorganisms 8(11):1747. https://doi.org/10.3390/microorganisms8 111747

Stal L (2012) Cyanobacterial mats and stromatolites. In: Whitton BA (ed) Ecology of Cyanobacteria II. Springer, New York, pp 61-120

Sumner DY, Jungblut AD, Hawes I, Andersen DT, Mackey TJ, Wall K (2016) Growth of elaborate microbial pinnacles in Lake Vanda, Antarctica. Geobiol 14:556-574

Suren A (1990) Microfauna associated with algal mats in melt ponds of the Ross Ice Shelf. Polar Biol 10:329-335

Sutherland DL (2009) Microbial mat communities in response to recent changes in the physiochemical environment of the meltwater ponds on the McMurdo Ice Shelf, Antarctica. Polar Biol 32:1023-1032

Sutherland DL, Howard-Williams C, Hawes I (2020) Environmental drivers that influence microalgal species in meltwater pools on the McMurdo Ice Shelf. Polar Biol, Antarctica. https://doi.org/ $10.1007 / \mathrm{s} 00300-020-02649-8$
Swithinbank C (1970) Ice movement in the McMurdo Sound area of Antarctica. Proceedings of the international symposium on antarctic glaciological exploration. Wallingford: IAHS, pp 472-486

Varin T, Lovejoy C, Jungblut AD, Vincent WF, Corbeil J (2010) Metagenomic profiling of Arctic microbial mat communities as nutrient scavenging and recycling systems. Limnol Oceanogr. https://doi.org/10.4319/lo.2010.55.5.1901

Varin T, Lovejoy C, Jungblut AD, Vincent WF, Corbeil J (2012) Metagenomic analysis of stress genes in microbial mat communities from Antarctica and the High Arctic. Appl Environ Microbiol 78:549-559

Vincent WF, James MR (1996) Biodiversity in extreme aquatic environments: Lakes, ponds and streams of the Ross Sea sector, Antarctica. Biodivers Conserv 5:1451-1471

Voss B, Bolhuis H, Fewer DP, Kopf M, Möke F, Haas F (2013) Insights into the physiology and ecology of the brackish-water-adapted Cyanobacterium Nodularia spumigena CCY9414 based on a genome-transcriptome analysis. PLoS ONE 8:e60224

Wait BR, Webster-Brown JG, Brown KL, Healy M, Hawes I (2006) Chemistry and stratification of Antarctic meltwater ponds I: Coastal ponds near Bratina Island, McMurdo Ice Shelf. Antarc Sci 18:515-524

Ward DM, Miller SR, Castenholz RW (2012) Cyanobacteria in geothermal habitats. In: Whitton BA (ed) Ecology of Cyanobacteria II. Springer, New York, pp 39-63

Wharton RAJ, Parker BC, Simmons GMJ (1983) Distribution, Species composition and morphology of algal mats in Antarctic Dry valley lakes. Phycol 22:355-365

Wong HL, Ahmed-Cox A, Burns BP (2016) Molecular ecology of hypersaline microbial mats: current insights and new directions. Microorganisms 4:6

Publisher's Note Springer Nature remains neutral with regard to jurisdictional claims in published maps and institutional affiliations. 